\title{
Assessing and Prioritizing the Critical Success Factors and Delays of Project Management Implementation: Empirical Evidence at Construction Projects in Jordan
}

\author{
Majd Mohammad Omoush ${ }^{1}$ \\ ${ }^{1}$ Business Administration Department, Business Faculty, Tafila Technical University, Jordan \\ Correspondence: Dr. Majd Mohammad Omoush, Tafila Technical University, Tafila, Jordan, P. O. Box 179, \\ Tafila 66110, Jordan. E-mail: omoushmajd@gmail.com
}

Received: July 26, 2020

Accepted: September 4, 2020

Online Published: September 27, 2020

doi:10.5539/ijbm.v15n10p117

URL: https://doi.org/10.5539/ijbm.v15n10p117

\begin{abstract}
The main goal of this research is to examine and then prioritize the critical success factors (CSFs) and delay reasons across the project management implementation stage. The study adopted the qualitative approach to introduce a full classification of the CSFs and delay reasons in project management. 44 studies have been reviewed in total to mine the various CSFs and delays based on conclusions of previous literature. This review leads to define a matrix of factors that are aligned with the project management in the context of the Jordanian construction project. Besides, the questionnaire instrument was designed based on outcomes of the critical analysis of literature; this instrument was administrated to a sample of 198 respondents across 20 Jordanian construction projects. The study sample entailed project managers, engineers, and senior department heads who were asked to assess the relevance and importance of the extracted CFSs. The questionnaire instrument was designed based on a 5-points Likert scale. Further, the data analysis was conducted based on the means values of the responses. The literature review resulted in categorizing the factors into five groups, namely, human's related factors, organizational and managerial, material factor, project-related factors, and the external environment and stakeholders' factors.

This research applied a taxonomy approach to classifying the mean values throughout three ideas, namely, the classification of the major success factors and delays, the exploration of the sub success factors and delays within each significant factor, and last the exploration of the most critical sub success factors and delays regardless of the significant factor they are linked to this group. According to the analyses results, the major success factors were evaluated based on priority ranking, and the results showed that the projects related factors group was the most crucial motive of either success or delays. Still, human-related factors were the least important factors group; however, the "coherent team." was the most sub factor evaluated. For the organizational and managerial sub-factors, the functional manager support was the most evaluated subfactor. Last, the materials sub-factor of the availability of materials was ranked as the most subfactor evaluated.
\end{abstract}

Keywords: project management, critical success factors (CSFs), delay factors, construction projects, Jordan

\section{Introduction}

Contracting and construction sector in Jordan of the most important economic sectors that contribute significantly to support gross domestic product (GDP), and create jobs and increase growth rates, especially that this sector directly with various communication economic sectors such as trade, industry, insurance and other sectors that are considered occupations supported (The Economic Policy Council 2018-2020). Moreover, affect it positively or negatively, perhaps the past years and the various events that accompanied them as a global financial crisis and the decline in the size of government and private projects, which makes them large for the work of the sector, and prompted some companies to exit from the market or stop working because of the current conditions (The Economic Policy Council, 2018-2020).

Excess costs and delays can appear because of a myriad of reasons for construction projects. When project costs or deadlines surpass their expected targets, customer loyalty, will be affected. The budget status does not fulfill the budget criteria anymore, which might lead to a further change in the schedule. The implications would be detrimental, particularly for developing countries whose prosperity indicator depends profoundly on their 
success in constructing infrastructure, particularly in road projects that form an essential segment of the sector (Kaliba, Muya, \& Mumba, 2009; Marzouk \& El-Rasas, 2014).

Several scholars acknowledged the problem of construction project delays and established its fundamental causes from the viewpoints of various stakeholders according to country, area, project type, and procurement methods (Abdelhadi, Dulaimi, \& Bajracharya, 2019; Hampton, Baldwin, \& Holt, 2012; Shahsavand, Marefat, \& Parchamijalal, 2018). In construction, a project can be assigned to three principal phases, which include planning, design and construction. Typically, throughout the construction process, the massive majority of project delays happen, with numerous unexpected factors being connected at all times (Chan \& Kumaraswamy, 1997). In this context, Construction delay implies an excess of period, whether in further than the date of the contract or outside the time-limit decided by the parties to complete the project. In each of these situations, a delay is always an expensive state (Marzouk \& El-Rasas, 2014). Delay was also described as an incident or act that expands the time needed to carry out the agreement or expresses itself as extra workdays (Zack, 2003).

The government is the primary client across many countries in the construction sector (Hiyassat, Hiyari, \& Sweis, 2016). Most public projects have significant delays and therefore go beyond the planned cost and time estimates (Ramanathan, Narayanan, \& Idrus, 2012). This issue can be seen more clearly in the conventional form of contracts where the cheapest bidder is selected whereby this procurement policy is followed in developing countries by the majority of government projects (Ramanathan et al., 2012).

The employment of project management can empower companies to place themselves appropriately in a current competitive market to achieve their business goals and requirements. Thus, companies can indulge in more effective project management to achieve better results, maximize success potential and minimize the likelihood of failing (Sanchez, Terlizzi, \& Moraes, 2017). As per Pinto and Slevin (1987), project management is a significant concern for the project manager from the outset. The intricacy of a project requires the manager's capacity to deal with a range of human, technological and economic concerns as well as their interactions. As a result, project managers have to react to challenging projects, often involving excessive workload and a hectic pace implementation. Hence, project management is a significant prerequisite for the implementation of construction projects and for the achievement of three demanding, conflicting and interconnected goals: scope, time and cost (Sanchez et al., 2017). These objectives should be accomplished from the project management perspective. In this sense, Businesses need to consider what fundamental elements are critical to properly tackle these factors in the success of a project (Cesar Felix Osorio, 2014). The causal link between project delays and overruns of costs is obvious, the success of any project heavily relies on the victorious project accomplishment without any delay and extra cost to avoid any dissatisfaction among stakeholders (Ramanathan et al., 2012).

Jordan is among developing countries that suffer from public projects delays and therefore cost overruns. In other words, the common delays lead to many conflicts between developers and contractors as well as the loss associated with these delays (Samarah \& Bekr, 2016; G. J. Sweis, 2013). Several studies have approached the issue trying to identify the critical factors of delays (Al-Hazim \& Salem, 2015; Al-Hazim, Salem, \& Ahmad, 2017; G. Sweis, Sweis, Hammad, \& Shboul, 2008). However, the success factors that can mitigate the delays and cost overruns are not addressed explicitly - in addition, prioritizing these factors is essential Endeavour yet they are not appropriately covered in relevant literature in the same way of similar studies conducted in other countries as this phenomenon is country and location-specific as we alluded earlier.

Hence, the study tackles the problem of finding out the CSFs that are shared across Jordanian construction projects, hence, figuring out the project delay reasons. Subsequently, this research shed lights on these factors to reduce the gap in the empirical literature and provide a better understanding of these delay reasons. Additional, the results will have managerial implications as it will be a roadmap to the decision-makers and construction company owners for further developments notably in Jordanian environment that is criticized of being observed of many delays in implementing even in sizeable public infrastructure projects.

\subsection{Research Objectives}

- This research aims at attaining the subsequent objectives:

- The research aims to identify the CSFs, also to define the prospective delay reason based on the empirical data of the Jordanian construction project.

- The research aims to provide results that intend to improve the adopted project management practices, particularly in emerging countries.

- The research aims to reduce the gaps in the literature by emphasizing the delay factors. Thus, the results will assess the project managers, the owners and decision-makers in improving the quality of the construction. 
- The research provides a systematic and scientific classification of the success and delays factors. Thus, it will clarify the project management implementation by taxonomies of these factors.

\section{Review of Related Works}

\subsection{Project Success Factors (CSFs) Concept}

Different project management scholars have recognized the success of a project along with the factors that influence this success in various respects. However, there is no standardized understanding and interpretation of these definitions, but there is agreement on the importance of these dimensions for the area of project management (Alexandrova \& Ivanova, 2012). Baker, Murphy, and Fisher (1983) distinguished that what matters is if project stakeholders are pleased with the outcomes. Perfect schedules and appropriately used budgets will not influence if the project's actual outcomes do not adhere to expectations and targets.

The first systematic definition of essential success factors for project management was developed by Schultz, Slevin, and Pinto (1987). They distinguish between two types of "strategic and tactical" factors that affect project outcomes at various phases of the project development cycle. For example, the "strategic" component comprises factors like project objectives, upper management and planning, whereas the "tactic" category comprised factors like customer consulting, choice of human resources and training staff. Pinto expanded the number of success factors by taking into account the characteristics of the different phases of the project life cycle. The study demonstrated that the impact of project success would vary between the various stages of the project life cycle and the performance metrics chosen by the analysts Misni and Lee (2017). The Kerzner (2001) concluded that project success is determined by completion, budget, and quality. In comparison, other scholars augmented these conclusion to include other factors such as achieving client company business goals, ensuring client satisfaction and reaching all other stakeholders' satisfaction (Shrnhur, Levy, \& Dvir, 1997).

In a nutshell, the "iron triangle"(time, cost, quality) itself was the first indicator of successful project management (De Wit, 1988), Which at last considered a just a component of the overall success of the project (Radujković \& Sjekavica, 2017) wherein all other factors play a pivotal factor in deciding the success of the project as these factors are seldom agreed upon in the literature.

\subsection{Related Works of Success and Delay Factors in Construction Projects}

Many studies were carried out to tackle delays and costs overruns in public construction projects. For example, a pivotal study in Gaza by Enshassi, Mohamed, and Abushaban (2009) showed that delays attributable to the closure of borders / major roads that result in material shortages are factors leading to project delays and cost overruns; Resources unavailability; inadequacy of project leadership skills; material price rise; well prepared and qualified workers shortage; and inferior quality of the materials and equipment needed. While the shutdown of borders and roads reported as a high priority factor in this study due to Gaza political unrest, the study conducted by G. Sweis et al.(2008) almost in the same period in a nearby country like Jordan which share the same geographical and demographic factor (except political issue) showed different conclusion. The study reported three factors inducing time slippage were found, namely inadequate expertise of contractors, engineers, and workers involved in the project; the contractors' inadequate project planning and scheduling, and harsh weather conditions on the worksite. Beside these factors secondary data from actual projects documents showed that government delay, design change, and weather conditions are the reason of delay for most projects in public projects.

Considering neighbor countries, in a study by Alhomidan (2013), Five factors have been suggested to be the primary reasons for the time overruns of projects. These involve inefficient administration and control of construction sites, the unforeseen construction project ground conditions, slow project decision-makers processes, and variation orders, particularly those provided by customers. From the study of the past literature, it can be discerned that various conclusions have been obtained in various countries. Even factor, such as data source, number of projects assessed, project execution time, form and size of projects can strongly affect performance.

Another study conducted by Al-Hazim and Salem (2015) to investigate the cost overrun caused by delay in most of the public road projects in Jordan. Their findings indicated that weather conditions, order variations, lack of workers, and terrain conditions are the most prominent critical factors that cause the delay and thus cost overruns. In addition, they alluded to managerial issues that contribute to this delay, such as planned cost for project construction, delay in decisions, management-labor relationship, and planning. The same result was echoed by Al-Hazim et al. (2017) in relevance to projects public construction projects.

By taking a novel look, the related literature of projects delays in Jordan concerned with factors that might hinder on-time completion of the public project from an engineering perspective. Even most of them mentioned 
the managerial issues partially; there is a lack of studies that approach the project management related factors explicitly.

In project management, a plethora of research has been conducted to determine the critical success and delay factors that can lead to a more successful implementation or hindrance of public projects within the time and budget constraints (Ahady, Gupta, \& Malik, 2017; Alias, Zawawi, Yusof, \& Aris, 2014; Cesar Felix Osorio, 2014; Chan \& Kumaraswamy, 1997; Frefer, Mahmoud, Haleema, \& Almamlook, 2018; Ika, Diallo, \& Thuillier, 2012; Sinesilassie, Tabish, \& Jha, 2018). To the purpose of the current study, the critical success factors were analyzed and prioritized in Table 1 to further assessed in Jordan public projects.

According to a preliminary analysis of these factors, five main categories have been developed, namely human-related, organizational and managerial, material, project, and external environment and stakeholders. In human-related categories, the relevant literature mentioned a number of critical factors such as competency of team and project manager and how well the team is organized and working in harmony (Sinesilassie et al., 2018; Viet Quoc, Bao Khac Quoc, Binh Van, Huong Thi Thanh, \& Thanh Quoc, 2019). Additionally, the internal motivation and commitment of the team have been asserted as a priority to achieve the desired goals as well as the strong relationship with customers to support the implementation process seamlessly (Ofori, 2013; Rahman \& Alzubi, 2015).

In the organizational and managerial category, the findings of the related work showed that the project and project manager should receive sufficient supports from top management as the main priority towards successful implementation (Gunduz \& Almuajebh, 2020; Pinto \& Slevin, 1987). The support can be represented by project champion who has the authority to provide resources and negotiate with stockholders to ensure that activities are accomplished impeccably (Viet Quoc et al., 2019). This can be achieved when the right project structure is applied based on project type and size (Gunduz \& Almuajebh, 2020).

Most of the literature in construction focused on the material as a crucial determinant in accomplishing project at the right time (Al-Hazim et al., 2017; Albogamy, Scott, Dawood, \& Bekr, 2013). They mentioned that material availability is essential not to encounter any slippage on-time (Enshassi et al., 2009). At the same time, the fluctuation of price and quality can contribute to cost overruns and conflict with the client (Al-Hazim \& Salem, 2015).

Numerous factors have been found in the literature in the sense of the project group, including the reasonable cost and time estimate, schedule urgency of the project operation, project size and importance within the project portfolio, project uniqueness (Halou, Samin, \& Ahmad, 2019; Viet Quoc et al., 2019). Sufficient budget and resources, specific priorities, efficient procurement and tendering processes (Gunduz \& Almuajebh, 2020) should all be correlated with all of these. Besides that, within a given time and budget, the amount of adjustments and order variations from the customer have a direct effect on the efficiency of activities and tasks (Msallam, Abojaradeh, Jrew, \& Zaki, 2015).

Lastly, the external environment and stakeholders' category has been assigned to a number of critical factors related to the surrounding environment and other stakeholders of the project (Al-Hazim et al., 2017; Enshassi et al., 2009; Gunduz \& Almuajebh, 2020; Msallam et al., 2015). These factors such as contractor financial strength, contractor's technical capacity, client's experience in the construction field and changing governmental regulations have a vital influence and can cause a delay as well as disputes among the involved parties (Gunduz $\&$ Almuajebh, 2020). In a similar fashion, the weather and terrain conditions have been asserted as unplanned external factors which can cause a delay and cost overruns (Enshassi et al., 2009; G. Sweis et al., 2008). 
Table 1. Taxonomies for Review of Success and delay factors in construction projects (CSFs) and delays

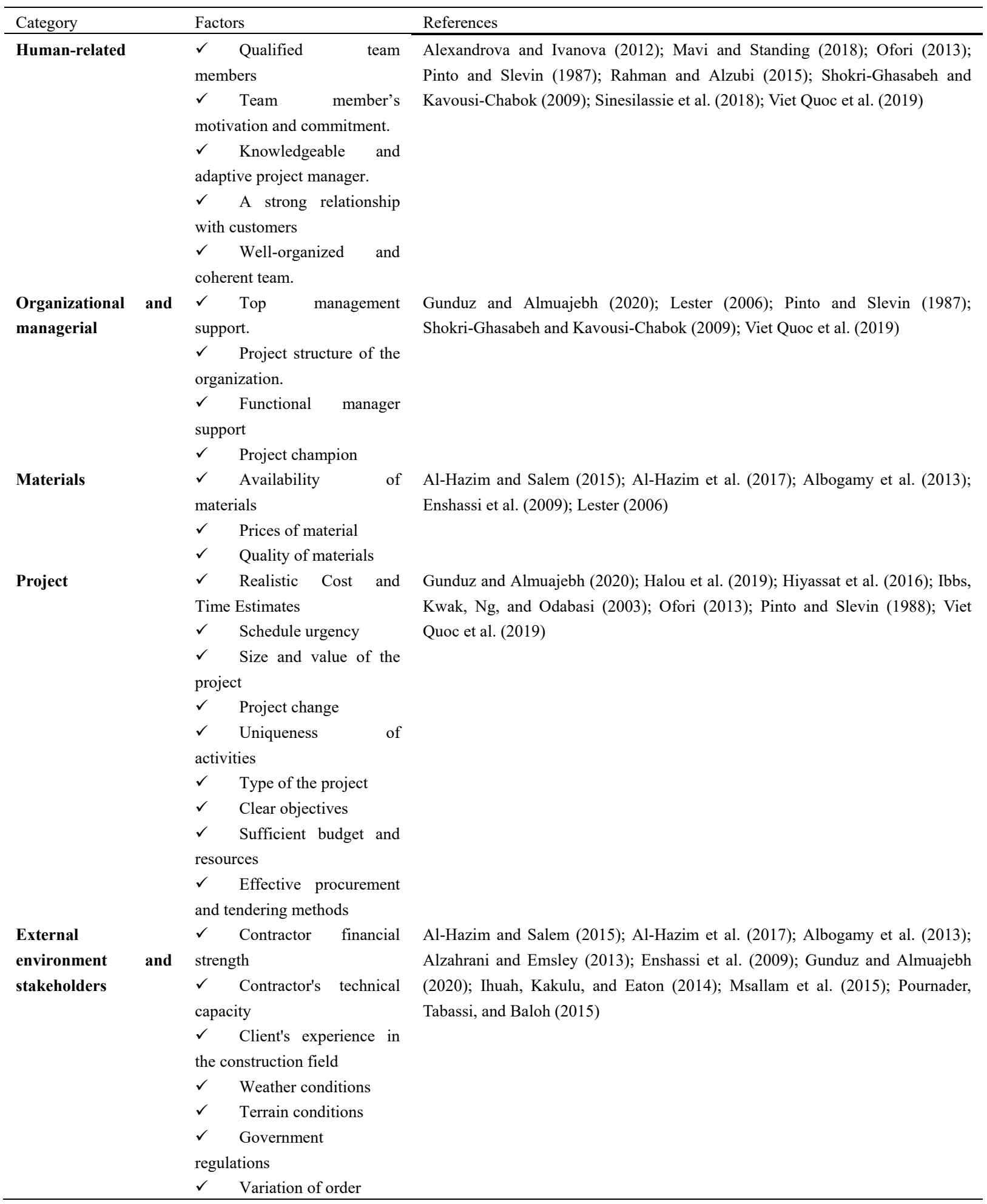

\section{Methodology}

This research paper adopted quantitative research method based on a critical literature review. In more definite details, the author reviewed 44 empirical papers that involve the identification of the CSFs and tackled the delay reasons from the project management viewpoint. The outcomes will be evaluated against the case of the construction projects in Jordan. The analysed literature mainly sampled groups of respondents with relevant experience, namely, project management, site engineers, technicians, and senior management. Furthermore, 
these investigations shed light on the academics and researchers' point that provided a shred of evidence from the emerging markets where it was noted through the search for references that most researchers concentrated on the causes of delay in construction projects in Jordan and did not concentrate on the reasons for success. From the researcher's point of view in this research, the factors of success and delay are some speculating through polling community opinions and the study Sample from the field.

\subsection{Statistical Analysis}

The descriptive methodology was used to accomplish the research goals and aims of the characterization of the CSFs. A random selection of (198) participants in (20) Jordanian building projects was chosen as seen in Table 1. Statistically speaking, this study was focused on the mean values reflecting the method of appraisal of the views of the researchers. In addition, a 5-point Likert scale was used in the administered research method In details, the instrument entails three groups, namely, the success factors were represented which entail five significant factors, the humans' related factors measured as five items, the organizational and managerial measured by four items (sub-factors), the material success factor measured by (3) subfactors, the project related factors measured by (9) subfactors. Last, the external environment and stakeholders related factors group measured by (7) subfactors. The researcher classified the means values throughout three ideas, first the classification of the significant success factors, second to explore the sub success factors within each significant success factor and third to explore what is the most critical sub success factors regardless of the significant success factor its part of it. The researcher checked for the reliability of the major success factors using Cronbach alpha approach. The results are included in the following tables.

Table 2. Sample's demographics' characteristics

\begin{tabular}{|c|c|c|c|}
\hline Variables & Categories & Counts & $\%$ \\
\hline \multirow{3}{*}{ Gender } & Males & 130 & 65.7 \\
\hline & Females & 68 & 34.3 \\
\hline & Total & 198 & 100.0 \\
\hline \multirow{5}{*}{ Age } & $20-29$ & 20 & 10.1 \\
\hline & $30-39$ & 50 & 25.3 \\
\hline & $40-49$ & 100 & 50.5 \\
\hline & $50+$ & 28 & 14.1 \\
\hline & Total & 198 & 100.0 \\
\hline \multirow{5}{*}{ Position } & Project Manager & 50 & 25.3 \\
\hline & Engineer & 50 & 25.3 \\
\hline & Senior Manager & 60 & 30.3 \\
\hline & Technician & 38 & 19.1 \\
\hline & Total & 198 & 100.0 \\
\hline \multirow{5}{*}{ Experience } & $<10$ years & 30 & 15.2 \\
\hline & $10-<15$ & 70 & 35.4 \\
\hline & $15-<20$ & 50 & 25.2 \\
\hline & $20+$ & 48 & 24.2 \\
\hline & Total & 98 & 100.0 \\
\hline
\end{tabular}

Table 2 indicates that the male individuals represented more than two thirds of the sample (65.7\%) while females represented less than one third $34.3 \%$ ).

Inspecting the age categories the research sample was characterized by the age category $(40-49)$ years as it represented $(50.5 \%)$ of the sample, while the younger age category $(20-29)$ years were the fewer individuals as they represented $(10.1 \%)$.

Engineers were the majority of the research sample, they represented more than three fourths of the sample $(25.3 \%)$ followed by the senior managers $(30.3 \%)$, the technicians $(19.1 \%)$ and finally the project managers were the least position category (25.3\%).

Analyzing the experience percentages easily can be detected that most of the samples' individuals were with long experience $(10-<15)$ years followed by the new experienced individuals $(<10)$ years $(35 \%)$, then the individuals with $(15-<20)$ years' experience $(25.2 \%)$ finally the longer experience individuals were the minority $(24.2 \%)$. 
Table 3. Reliability analysis (pilot sample) using the approach of Cronbach alpha

\begin{tabular}{llll}
\hline Success factors & No. of items & Items reference & C.A value \\
\hline Human Related & 5 & $\mathrm{a} 1-\mathrm{a} 5$ & 0.795 \\
Organizational And Managerial & 4 & $\mathrm{~b} 6-\mathrm{b} 9$ & 0.750 \\
Material & 3 & $\mathrm{c} 10-\mathrm{c} 12$ & 0.783 \\
Factors Related Project & 9 & $\mathrm{D} 13-\mathrm{d} 21$ & 0.805 \\
External Environment And Stack Holder & 7 & $\mathrm{~F} 22-\mathrm{f} 28$ & 0.830 \\
All Sub Factors' Items & 28 & $\mathrm{~A} 1-\mathrm{f} 28$ & 0.941 \\
\hline
\end{tabular}

Table 3 indicates the results of reliability analysis using the approach of Cronbach alpha. The minimum observed reliability value $(0.750)$ was assigned to the organizational and managerial success factor. All other values were greater telling that the success \&delays factors reflected a high reasonable reliability values

\subsubsection{Analyzing the Main (Major) Success Factors}

Table 4. Arithmetic means, standard deviations, and average index for the major success \&delays factors

\begin{tabular}{lllll}
\hline Success factors & Mean & sd & MI & Mean order \\
\hline Human Related & 3.794 & 0.57 & 75.88 & 5 \\
Organizational And Managerial & 3.842 & 0.48 & 76.84 & 4 \\
Materials & 3.980 & 0.49 & 79.60 & 2 \\
Projects Related Factors & 4.029 & 0.40 & 80.58 & 1 \\
External Environment And Stack Holder & 3.869 & 0.37 & 77.38 & 3 \\
\hline
\end{tabular}

Table 4 presents the means, standard deviations and mean index for the major factors. The results inform that the projects related factors was the most factor being addressed by the research sample as it ranked the first order mean of evaluation (4.029) followed by the materials factor (3.980) the External Environment and Stack holder (3.869). It was observed that the humans related success factor was the less important factor being reported (3.794) preceded directly by the organizational and managerial factor (3.842).

\subsubsection{Internal Analysis of the Main (Major) Success Factors through the Related Sub Factors}

\subsubsection{Analyzing the Humans Related Sub Factors}

Table 5. Arithmetic means, standard deviations, and average index for the Humans Related success \&delays factors

\begin{tabular}{lllll}
\hline Humans Related Sub Factors Success & Mean & SD & MI & Mean Order \\
\hline a1 & 3.827 & 0.94 & 76.54 & 2 \\
a2 & 3.724 & 0.93 & 74.48 & 4 \\
a3 & 3.684 & 1.01 & 73.68 & 5 \\
a4 & 3.806 & 0.82 & 76.12 & 3 \\
a5 & 3.929 & 0.85 & 78.58 & 1 \\
Humans Related success factor & 3.794 & 0.57 & 75.88 & \\
\hline
\end{tabular}

Table 5 presents the means, standard deviations and mean index for the sub factors (items) representing the Humans Related factor. the sub factor coded (a5) "Well-organized and coherent team." was the most sub factor being observed among the other sub factors as it ranked the first order mean of evaluation (3.929) followed by the sub success factor coded (a1) "Qualified team members" as it ranked the second mean order (3.827). It was observed that the less important sub factor was addressed by the code (a3) "Knowledgeable and adaptive project manager." factor being reported (3.684). 


\subsubsection{Analyzing the Organizational and Managerial Sub Factors}

Table 6. Arithmetic means, standard deviations, and average index for the organizational and managerial sub success \&delays factors

\begin{tabular}{lllll}
\hline Organizational And Managerial Sub Factors Success & Mean & SD & Mi & Mean Order \\
\hline b1 & 3.969 & 0.85 & 79.38 & 2 \\
b2 & 3.653 & 1.00 & 73.06 & 4 \\
b3 & 3.990 & 0.78 & 79.80 & 1 \\
b4 & 3.755 & 0.85 & 75.10 & 3 \\
organizational and managerial & 3.842 & 0.48 & 76.84 & \\
\hline
\end{tabular}

Table 6 suggest the means, standard deviations and mean index for the sub factors (items) representing the organizational and managerial success factor. the sub factor coded (b3) "Functional manager support" was the most sub success factor being evaluated among the other sub factors as it ranked the first order mean of evaluation (3.990) followed by the sub success factor coded (b1) "Top management support." as it ranked the second mean order (3.969). The less important sub success factor was recognized by the sub factor coded (b2) "Project structure of the organization." factor as it was reported by a mean of (3.653)

\subsubsection{Analyzing the Materials Sub Factors}

Table 7. Arithmetic means, standard deviations, and average index for the Materials sub success \&delays factors

\begin{tabular}{lllll}
\hline Materials Sub Factors Success & Mean & SD & MI & Mean order \\
\hline c1 & 4.163 & 0.74 & 83.26 & 1 \\
c2 & 3.990 & 0.73 & 79.80 & 2 \\
c3 & 3.786 & 0.80 & 75.72 & 3 \\
Materials success factor & 3.980 & 0.49 & 79.60 & \\
\hline
\end{tabular}

Table 7 suggest the means, standard deviations and mean index for the sub success factors (items) representing the Materials success factor. the sub factor coded (c1) "Availability of materials" was the most sub success factor being addressed among the other sub factors as it ranked the first order mean of evaluation (4.163) then the sub factor coded (c2) "Prices of material" as it ranked the second mean order (3.990). The less important sub success factor was represented by the sub s factor coded (c3) "Quality of materials". As it was evaluated by a mean of (3.786).

\subsubsection{Analyzing the Project Are Related Factors Sub Factors}

Table 8. Arithmetic means, standard deviations, and average index for the Project's related sub success \& delays factors

\begin{tabular}{lllll}
\hline Project's Related Factors Sub Factors Success & Mean & SD & MI & Mean Order \\
\hline d1 & 3.796 & 0.91 & 75.92 & 9 \\
d2 & 4.235 & 0.70 & 84.70 & 2 \\
d3 & 3.857 & 0.96 & 77.14 & 8 \\
d4 & 3.878 & 0.90 & 77.56 & 6 \\
d5 & 3.867 & 0.92 & 77.34 & 7 \\
d6 & 4.245 & 0.72 & 84.90 & 1 \\
d7 & 4.102 & 0.94 & 82.04 & 4 \\
d8 & 4.204 & 0.75 & 84.08 & 3 \\
d9 & 4.082 & 0.60 & 81.64 & 5 \\
Project's related factors & 4.029 & 0.40 & 80.58 & \\
\hline
\end{tabular}

Table 8 reflects the means, standard deviations and mean index for the sub success factors (items) representing the Project's related factors. the sub factor coded (d6) "Type of the project." was the most important sub factor being reported among the other sub factors as it ranked the first order mean of evaluation (4.245) followed by the 
sub factor coded (d2) "Schedule urgency" as it ranked the second mean order (4.235). The less important sub factor was addressed by the sub factor coded (d1) "Realistic Cost and Time Estimates" factor as it was reported by a mean of (3.796).

\subsubsection{Analyzing the External Environment and Stack Holder Sub Factors}

Table 9. Arithmetic means, standard deviations, and average index for the external environment and stack holder sub success \&delays factors

\begin{tabular}{lllll}
\hline External Environment And Stack Holder Sub Factors Success & Mean & SD & MI & Mean Order \\
\hline e1 & 4.245 & 0.56 & 84.90 & 1 \\
e2 & 3.622 & 0.81 & 72.44 & 7 \\
e3 & 3.745 & 0.74 & 74.90 & 4 \\
e4 & 3.745 & 0.87 & 74.90 & 4 \\
e5 & 3.929 & 0.86 & 78.58 & 2 \\
e6 & 3.898 & 0.62 & 77.96 & 3 \\
e7 & 3.898 & 0.62 & 77.96 & 3 \\
External Environment and Stack holder & 3.869 & 0.37 & 77.38 & \\
\hline
\end{tabular}

Table 9 reflects the means, standard deviations and mean index for the sub success factors (items) representing the External Environment and Stack holder success factor. the sub factor coded (e1) "Contractor financial strength." was the most important sub factor being reported among the other sub factors as it ranked the first order mean of evaluation (4.245) followed by the sub factor coded (e5) "Terrain conditions" as it ranked the second mean order (3.929). The less important sub factor was addressed by the sub factor coded (e2) "Contractor's technical capacity." factor as it was reported by a mean of (3.622).

\subsubsection{Analyzing All the Sub Success Factors (Items)}

Table 10. Arithmetic means, standard deviations, and average index for each of the variables all success and reconcile delay (items)

\begin{tabular}{|c|c|c|c|c|}
\hline Success Factors & Mean & Sd & Mi & Mean Order \\
\hline A1 & 3.827 & 0.94 & 76.54 & 18 \\
\hline A2 & 3.724 & 0.93 & 74.48 & 25 \\
\hline A3 & 3.684 & 1.01 & 73.68 & 26 \\
\hline A4 & 3.806 & 0.82 & 76.12 & 19 \\
\hline A5 & 3.929 & 0.85 & 78.58 & 11 \\
\hline B1 & 3.969 & 0.85 & 79.38 & 10 \\
\hline B2 & 3.653 & 1.00 & 73.06 & 27 \\
\hline B3 & 3.990 & 0.78 & 79.80 & 8 \\
\hline B4 & 3.755 & 0.85 & 75.10 & 22 \\
\hline C1 & 4.163 & 0.74 & 83.26 & 5 \\
\hline $\mathrm{C2}$ & 3.990 & 0.73 & 79.80 & 8 \\
\hline C3 & 3.786 & 0.80 & 75.72 & 21 \\
\hline D1 & 3.796 & 0.91 & 75.92 & 20 \\
\hline D2 & 4.235 & 0.70 & 84.70 & 3 \\
\hline D3 & 3.857 & 0.96 & 77.14 & 17 \\
\hline D4 & 3.878 & 0.9 & 77.56 & 15 \\
\hline D5 & 3.867 & 0.92 & 77.34 & 16 \\
\hline D6 & 4.245 & 0.72 & 84.90 & 1 \\
\hline D7 & 4.102 & 0.94 & 82.04 & 6 \\
\hline D8 & 4.204 & 0.75 & 84.08 & 4 \\
\hline D9 & 4.082 & 0.60 & 81.64 & 7 \\
\hline E1 & 4.245 & 0.56 & 84.90 & 1 \\
\hline E2 & 3.622 & 0.81 & 72.44 & 28 \\
\hline E3 & 3.745 & 0.74 & 74.90 & 23 \\
\hline E4 & 3.745 & 0.87 & 74.90 & 23 \\
\hline E5 & 3.929 & 0.86 & 78.58 & 11 \\
\hline E6 & 3.898 & 0.62 & 77.96 & 13 \\
\hline E7 & 3.898 & 0.62 & 77.96 & 13 \\
\hline
\end{tabular}

Table 10 reflects the means, standard deviations and mean index for the sub factors (items). It was revealed that 
the first order was shared by two sub factors coded (d6) which states "Type of the project. "and the sub factor coded (e1) which states "Qualified team members." as they both reflected the most important sub success factor being reported among the other sub factors (4.245) followed by the sub success factor coded (d2) which states "Schedule urgency" as it ranked the second mean order (4.235). The less important sub factor was addressed by the sub success \&delays factor coded (e2) "Contractor's technical capacity" factor as it was reported by a mean of (3.622).

\section{Result and Conclusion}

1. Research findings based on the assessment analysis of 44 articles show that the causes of project performance are the same as those of project delays.

2. The research results throughout analyzing the questionnaire distributed to the managers, engineers and specialists in construction projects figured out that there are essential factors that help in the success and delays of the projects mentioned in the above taxonomy

3. For the significant success factors based on priority ranking analysis, the results points out that the Projects related factors were the most crucial success and delays factor while the factor Human Related was the lea important factor being evaluated For the humans' related factors the sub factor "coherent team." was the most sub factor evaluated, For the organizational and managerial sub-factors "Functional manager support" was the most sub factor evaluated finally For the materials sub-factors "Availability of materials" was the most sub factor evaluated.

4. This research distinguished by only adding important determining factors and delays in project execution, demonstrating that success and delay are related factors.

\section{References}

Abdelhadi, Y., Dulaimi, M. F., \& Bajracharya, A. (2019). Factors influencing the selection of delay analysis methods in construction projects in UAE. International Journal of Construction Management, 19(4), 329-340. https://doi.org/10.1080/15623599.2018.1435155

Ahady, S., Gupta, S., \& Malik, R. (2017). A critical review of the causes of cost overrun in construction industries in developing countries. International Research Journal of Engineering and Technology, 4(03), 2550-2558.

Albogamy, A., Scott, D., Dawood, N., \& Bekr, G. (2013). Addressing crucial risk factors in the Middle East construction industries: a comparative study of Saudi Arabia and Jordan. Paper presented at the Sustainable Building Conference Coventry University, West Midlands, UK.

Alexandrova, M., \& Ivanova, L. (2012). Critical success factors of project management: empirical evidence from projects supported by EU programmes. Systematic Economic Crisis: Current issues and persperctive. https://doi.org/10.1016/j.ijproman.2011.03.005

Al-Hazim, N., \& Salem, Z. A. (2015). Delay and cost overrun in road construction projects in Jordan. International Journal of Engineering \& Technology, 4(2), 288. https://doi.org/10.14419/ijet.v4i2.4409

Al-Hazim, N., Salem, Z. A., \& Ahmad, H. (2017). Delay and cost overrun in infrastructure projects in Jordan. Procedia engineering, 182, 18-24. https://doi.org/10.1016/j.proeng.2017.03.105

Alhomidan, A. (2013). Factors affecting cost overrun in road construction projects in Saudi Arabia. International Journal of Civil \& Environmental Engineering, 13(3), 1-4.

Alias, Z., Zawawi, E., Yusof, K., \& Aris, N. (2014). Determining critical success factors of project management practice: A conceptual framework. Procedia-Social and Behavioral Sciences, 153, 61-69. https://doi.org/10.1016/j.sbspro.2014.10.041

Alzahrani, J. I., \& Emsley, M. W. (2013). The impact of contractors' attributes on construction project success: A post construction evaluation. International Journal of Project Management, 31(2), 313-322. https://doi.org/10.1016/j.ijproman.2012.06.006

Baker, B. N., Murphy, D. C., \& Fisher, D. (1983). Factors Affecting Project Success. In Cleland, D. I., \& King, W. R. (Eds.), Systems analysis and Project management. New York: McGraw Hill. https://doi.org/10.1002/9780470172353.ch35

Cesar, F. O., Luis, P. Z., Eduardo, S., \& SÃcrgio, F. P. (2014). Critical Success Factors in Project Management: An Exploratory Study of an Energy Company in Brazil. Global Journal of Management and Business Research. https://doi.org/10.1057/9781137356260.0013 
Chan, D. W., \& Kumaraswamy, M. M. (1997). A comparative study of causes of time overruns in Hong Kong construction projects. International Journal of Project Management, 15(1), 55-63. https://doi.org/10.1016/s0263-7863(96)00039-7

De Wit, A. (1988). Measurement of project success. International Journal of Project Management, 6(3), 164-170. https://doi.org/10.1016/0263-7863(88)90043-9

Enshassi, A., Mohamed, S., \& Abushaban, S. (2009). Factors affecting the performance of construction projects in the Gaza strip. Journal of Civil engineering and Management, 15(3), 269-280. https://doi.org/10.3846/1392-3730.2009.15.269-280

Frefer, A., Mahmoud, M., Haleema, H., \& Almamlook, R. (2018). Overview success criteria and critical success factors in project management. Industrial engineering \& management, 7(1), 2169-0316. https://doi.org/10.4172/2169-0316.1000244

Gunduz, M., \& Almuajebh, M. (2020). Critical Success Factors for Sustainable Construction Project Management. Sustainability, 12(5), 1990. https://doi.org/10.3390/su12051990

Halou, M., Samin, R., \& Ahmad, M. (2019). Impacts of change management on risk and cost management of a construction projects. Journal of Project Management, 4(2), 157-164. https://doi.org/10.5267/j.jpm.2019.1.005

Hampton, G., Baldwin, A. N., \& Holt, G. (2012). Project delays and cost: stakeholder perceptions of traditional v. PPP procurement. Journal of Financial Management of Property and Construction. https://doi.org/10.1108/13664381211211055

Hiyassat, M. A., Hiyari, M. A., \& Sweis, G. J. (2016). Factors affecting construction labour productivity: a case study of Jordan. International Journal of Construction Management, 16(2), 138-149. https://doi.org/10.1080/15623599.2016.1142266

Ibbs, C. W., Kwak, Y. H., Ng, T., \& Odabasi, A. M. (2003). Project delivery systems and project change: Quantitative analysis. Journal of Construction Engineering and Management, 129(4), 382-387. https://doi.org/10.1061/(asce)0733-9364(2003)129:4(382)

Ihuah, P. W., Kakulu, I. I., \& Eaton, D. (2014). A review of Critical Project Management Success Factors (CPMSF) for sustainable social housing in Nigeria. International Journal of Sustainable Built Environment, 3(1), 62-71. https://doi.org/10.1016/j.ijsbe.2014.08.001

Ika, L. A., Diallo, A. B., \& Thuillier, D. (2012). Critical success factors for World Bank projects: An empirical investigation. https://doi.org/10.1016/j.jproman.2011.03.005

Jordan Economic Growth Plan (2018-2022). The Economic Policy Council Retrieved from http://extwprlegs1.fao.org/docs/pdf/jor170691.pdf

Kaliba, C., Muya, M., \& Mumba, K. (2009). Cost escalation and schedule delays in road construction projects in

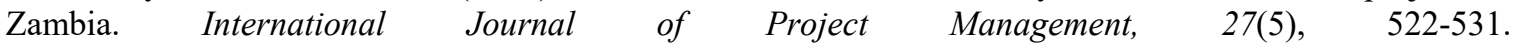
https://doi.org/10.1016/j.ijproman.2008.07.003

Kerzner, H. (2001). Project management: a systems approach to planning, scheduling, and controlling: John Wiley \& Sons. https://doi.org/10.1177/875697280303400409

Lester, A. (2006). Project management, planning and control: managing engineering, construction and manufacturing projects to PMI, APM and BSI standards: Elsevier. https://doi.org/10.1016/b978-075066956-6/50031-9

Marzouk, M. M., \& El-Rasas, T. I. (2014). Analysing delay causes in Egyptian construction projects. Journal of Advanced Research, 5(1), 49-55. https://doi.org/10.1016/j.jare.2012.11.005

Mavi, R. K., \& Standing, C. (2018). Critical success factors of sustainable project management in construction: A fuzzy DEMATEL-ANP approach. Journal of cleaner Production, 194, 751-765. https://doi.org/10.1016/j.jclepro.2018.05.120

Msallam, M., Abojaradeh, M., Jrew, B., \& Zaki, I. (2015). Controlling of variation orders in highway projects in Jordan. Journal of Engineering and Architecture, 3(2), 95-104. https://doi.org/10.15640/jea.v3n2a11

Ofori, D. (2013). Project Management Practices and Critical Success Factor: A Developing Country Perspective. International Journal of Biometrics, 8, 14. https://doi.org/10.5539/ijbm.v8n21p14

Pinto, J. K., \& Slevin, D. P. (1987). Critical factors in successful project implementation. IEEE transactions on 
Engineering Management, (1), 22-27. https://doi.org/10.1109/tem.1987.6498856

Pinto, J. K., \& Slevin, D. P. (1988). Critical Success Factors in Effective Project implementation*. Project management handbook, 479, 167-190. https://doi.org/10.1002/9780470172353.ch20

Pournader, M., Tabassi, A. A., \& Baloh, P. (2015). A three-step design science approach to develop a novel human resource-planning framework in projects: The cases of construction projects in USA, Europe, and Iran. International Journal of Project Management, 33(2), 419-434. https://doi.org/10.1016/j.ijproman.2014.06.009

Radujković, M., \& Sjekavica, M. (2017). Project management success factors. Procedia engineering, 196, 607-615. https://doi.org/10.1016/j.proeng.2017.08.048

Rahman, A., \& Alzubi, Y. (2015). Exploring key contractor factors influencing client satisfaction level in dealing with construction project: An empirical study in Jordan. International Journal of Academic Research in Business and Social Sciences, 5(12), 109-126. https://doi.org/10.6007/ijarbss/v5-i12/1935

Ramanathan, C., Narayanan, S., \& Idrus, A. B. (2012). Construction delays causing risks on time and cost-a critical review. Construction Economics and Building, 12(1), 37-57. https://doi.org/10.5130/ajceb.v12i1.2330

Samarah, A., \& Bekr, G. A. (2016). Causes and effects of delay in public construction projects in Jordan. American Journal of Engineering Research, 5(5), 87-94. https://doi.org/10.7763/ijet.2012.v4.441

Sanchez, O. P., Terlizzi, M. A., \& Moraes, H. R. O. C. d. (2017). Cost and time project management success factors for information systems development projects. International Journal of Project Management, 35, 1608-1626. https://doi.org/10.1016/j.ijproman.2017.09.007

Schultz, R. L., Slevin, D. P., \& Pinto, J. K. (1987). Strategy and tactics in a process model of project implementation. Interfaces, 17(3), 34-46. https://doi.org/10.1287/inte.17.3.34

Shahsavand, P., Marefat, A., \& Parchamijalal, M. (2018). Causes of delays in construction industry and comparative delay analysis techniques with SCL protocol. Engineering, Construction and Architectural Management. https://doi.org/10.1108/ecam-10-2016-0220

Shokri-Ghasabeh, M., \& Kavousi-Chabok, K. (2009). Generic Project Success and Project Management Success Criteria and Factors: Literature Review and Survey.

Shrnhur, A. J., Levy, O., \& Dvir, D. (1997). Mapping the dimensions of project success. Project management journal, 28(2), 5-13. https://doi.org/10.1111/1467-9310.00047

Sinesilassie, E., Tabish, S., \& Jha, K. (2018). Critical factors affecting cost performance: a case of Ethiopian public construction projects. International Journal of Construction Management, 18(2), 108-119. https://doi.org/10.1080/15623599.2016.1277058

Sweis, G. J. (2013). Factors affecting time overruns in public construction projects: The case of Jordan. International Journal of Business and Management, 8(23), 120. https://doi.org/10.5539/ijbm.v8n23p120

Sweis, G., Sweis, R., Hammad, A. A., \& Shboul, A. (2008). Delays in construction projects: The case of Jordan. International Journal of Project Management, 26(6), 665-674. https://doi.org/10.1016/j.ijproman.2007.09.009

Viet Quoc, P., Bao Khac Quoc, N., Binh Van, T. U., Huong Thi Thanh, P., \& Thanh Quoc, L. E. (2019). Critical Success Factors of Project Management : The Case of Construction Related Projects in Vietnam. The Journal of Asian Finance, Economics and Business, 6(2), 223-230. https://doi.org/10.1109/cyberneticscom.2016.7892567

Zack, J. G. (2003). Schedule delay analysis; is there agreement. Paper presented at the Proc. PMI-CPM college of performance spring conf. https://doi.org/10.1109/milcom.1994.473978 


\section{Appendix}

Questionnaire

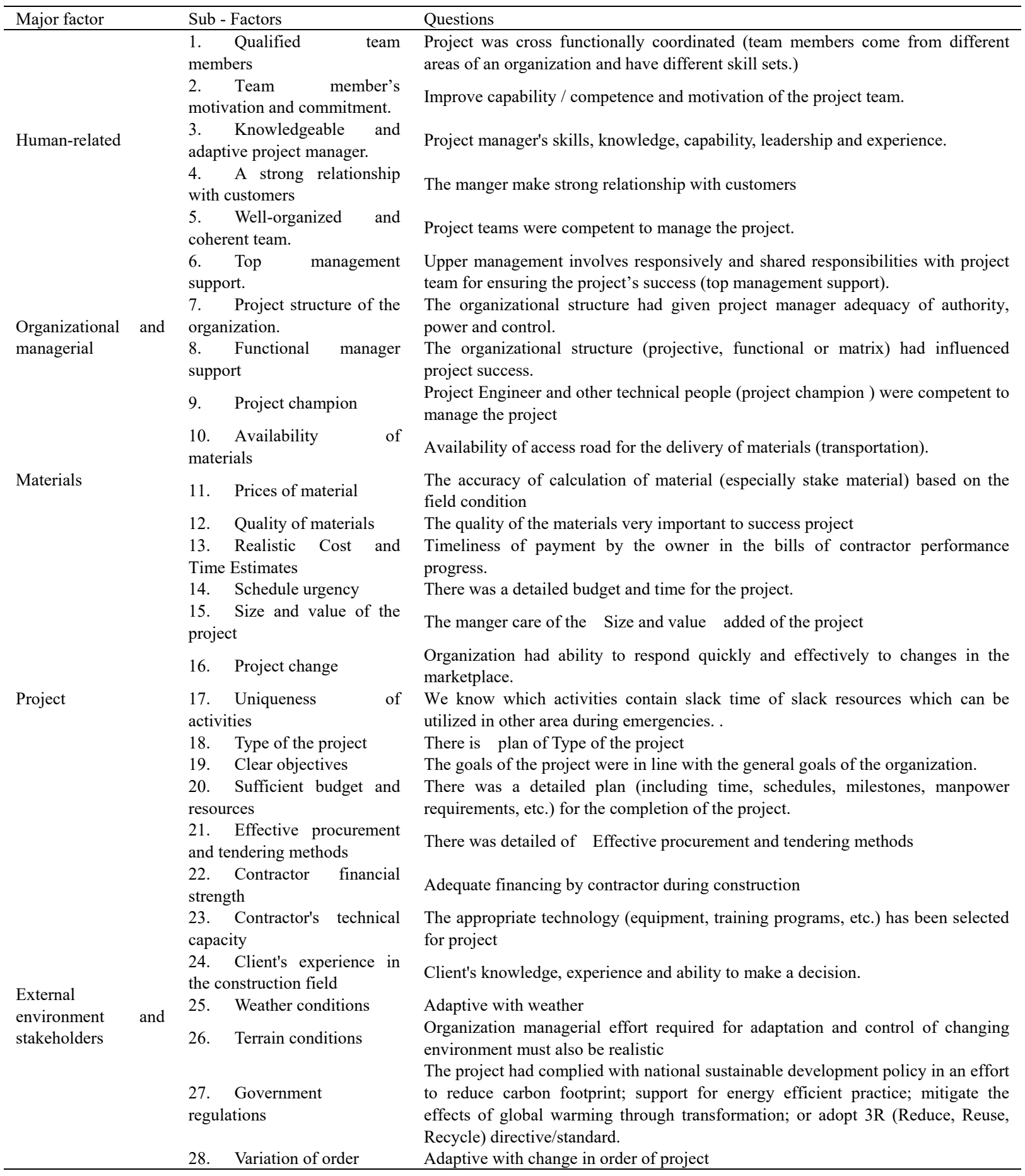

\section{Copyrights}

Copyright for this article is retained by the author(s), with first publication rights granted to the journal.

This is an open-access article distributed under the terms and conditions of the Creative Commons Attribution license (http://creativecommons.org/licenses/by/4.0/). 